\title{
Sustainable Designs between Traditional \& Contemporary Architecture
}

\author{
Shatha Y. Alsheikh ${ }^{1} \&$ Bayda H. Saffo ${ }^{2} \&$ Niam B. Manona ${ }^{3}$ \\ ${ }^{1}$ Department of Architecture, Mosul University, Mosul, Iraq \\ ${ }^{2}$ Mosul University, Mosul, Iraq \\ ${ }^{3}$ Department of Architecture, Mosul University, Mosul, Iraq \\ Correspondence: Shatha Y. Alsheikh, Mosul University, Mosul, Iraq. \\ Email: yacoubshatha@yahoo.com
}

Doi: 10.23918/eajse.v6i1p129

\begin{abstract}
Research discusses the importance of sustainable designs and how to achieve them, not only as a new concept in contemporary architecture, but as an extension of technologies and thoughts related to traditional architecture and identity, where the elements of sustainable, spontaneous and implicit design have been integrated with the underlying conceptual thought, using local building materials and simple studied techniques derived from the spatial contexts. With the beginning of the third millennium, sustainable buildings were no longer considered as an academic luxury or purely theoretical trends, but they represented innovative patterns of applied global trends and professional practices, and their levels started to be formed, in the architectural and constructional sectors worldwide. Research problem has been formed by the unclear definition of the levels of achieving sustainable designs in each of the traditional architecture and its counterpart of the contemporary, and its objective has been determined by defining those levels. While research methodology has established a theoretical framework defining those levels with primary and secondary vocabularies, in traditional architecture according to: (the urban fabric, intellectual and design trends, architectural elements employed, and the current treatments to the elements), it has been found that the significant levels of achieving sustainability in contemporary architecture, include exploring two other levels, added to those four, concerning, the building performance aspects adding a new forth design dimension, "time", and, the humanistic aspects, as well as the exploration of a primary vocabulary involved in the level of the intellectual and design trends. Those levels are then applied to a sample of contemporary sustainable design projects to explore their utilization. It was concluded that the implicit levels of sustainable designs achievement of traditional architecture stemming from the identity of place, have set strong basis, continued to be employed in different procedures, in contemporary sustainable designs, reflecting the high-technological and innovative identity of the age, as well as, the activation of those levels, academically and practically in the context of design tasks.
\end{abstract}

Keywords: Sustainable Designs, Dynamic Architecture, Traditional Architecture

\section{Introduction}

As society enters into a new age of environmental and social self- consciousness, a new architecture is emerging that is more complex, innovative and dynamic than ever before. Contemporary architecture is obliged to address previously ignored environmental, social and technological questions. (mattJohnsonarchitect.wordpress.com, 2014). Thus, the concept of sustainable architecture has emerged as one of the concepts, which interested in natural environments influencing exclusively the physical environments, tending to use natural materials, and producing clean energy, reducing of waste pollutants and maintenance of the natural resource base for the future, in order to protect individuals and help them to improve their health and their potential productivity. This study focused on identifying clear knowledge of the levels of achieving sustainability in architectural design in both traditional and contemporary architecture and those levels diversified in the first, through the innate and experimental compatibility, with environment and the efficient exploitation of natural resources through trial and error, and the fact that architecture is the essential envelope innovated to protect human beings from external, natural and environmental conditions, and this was achieved in the 
traditional architecture and activated in contemporary counterparts in various levels, while some of them associated with the design, constructional, and performance aspects of the building, others related to the humanistic ones, represented by respect of its users, to different environmental, urban and designing issues of the site. Moreover, it has been explored that the basis of those levels formed in the traditional architecture are continued to be employed in contemporary sustainable architecture in away expressing the identity of age.

\section{Sustainability in Architecture/ the Importance of the Subject}

The research discussed the importance of the sustainability concept in the contemporary engineering and professional spheres, in general and architectural circles in particular. Professionals themselves experimenting with alternative energy sources, the development of new materials, techniques and methods of the designs, implementation, operation and maintenance that contribute to the building form development, increasing its efficiency performance, with lower costs, and safe comfortable urban environments. James Steel in his book (green architecture), stresses the importance of the previous presentation confirming that sustainable designs require skills like, analysis, comparisons, the summaries and conclusions which lead to the aesthetic options instead of formal patterns, so architectural entities in this age are no longer in isolation from the pressing environmental issues (Tanta University, 2011). Sometimes, in contemporary green architecture, seems to preclude the striking forms of traditional modern architecture, for the sake of sustainable issues. (mattJohnsonarchitecture.wordpress.com, 2014). Also, the other important point, is building industry, where the architectural entities are major consumers of natural resources such as land, water, energy and materials, and the resulting of solid waste, noise and pollution, throughout that operation.

Another importance of the sustainable design solutions goes beyond health aspects, as in administrative buildings, for example, contribute not only to reduce energy consumption, but to improve the health of the users and raise their production rates. Examples noted that the staff of the natural areas of their offices showed greater satisfaction with the work and were less stressful, and sales in the stores marketing lighted through the roof vents were higher by $40 \%$, also found that the performance of the students in the classrooms of the naturally lit best by $20 \%$. (Tanta University, 2011). Studies also indicated the importance of dynamic sustainable designs, which reveals three major innovations: changing shapes, clean industrial production of units and self-production of clean energy, where dynamic buildings follow the sun and move to the wind, making design more efficient and environment friendly with no risk of pollution (www.busyboo.com, 2007).

What was mentioned in the specialized literature about the importance of the subject in the contemporary architecture has been consistent with its counterpart of traditional literature, which presented the clear overlap of some of the tools of sustainability with the social and humanitarian systems embodied in the architectural products and lifestyle (Shaheen \& Al-Zubaidy, 2008). To conclude, the general concept of sustainability played an important role in the design solutions, whether, in the traditional architectural models based on innate spontaneity, or the contemporary models based on technological developments available. It is also noted that there is a radical change occurred in the patterns of these models in each of the design aspects, the constructional and performance aspects, with its goal of achieving the quality of integrated building forms, economically, socially and environmentally, thus stressing the employment of that concept in the design tasks. 


\section{Sustainable Designs in Architectural Literature/Research Objective, its Problem \& Methodology}

Research discussed and evaluated the knowledge in the architectural studies, concerning sustainable designs especially the application of their ideas, to explore research problems, where the architects found themselves trapped between the writings and theories of global artifacts adopting these ideas, on the one hand, with the difficulty of verification and application in local environments in a way that promote the identity of the different societies, on the other hand. Also, it was emerged among those problems, on the level of design dimension, the problem of giving priority to the idea of fascination in the architectural products concentrating on the values of form designed and the extreme use of materials more than involving values of sustainability associated with the environment, economy, performance and construction. (Selim, 2011). For example: the most stylistically striking architects like Santiago Calatrava, whose daring feats of architecture have distinguished him as the most formally contemporary architect, has been criticized for exhibiting little interest in environmentally responsible architecture (Goldhagen, 2014).

Emerged also, the problematic stereotyping of particular forms of international firms and that prevailed in the third millennium, which may harm the identity and contexts of the place (Selim, 2011). As well as the problem of identifying aspects of sustainable designs, focusing on the rationalization of energy consumption and physical comfort to users without attention of identity and cultural characteristics of place (www.arab-eng.org, 2008). There were also problems on the level of constructional / technical dimension, through growing applications of sustainability in the construction industry (Tanta University, 2011).

Other problems include the implicit knowledge on some levels, as the level of performance of dynamic sustainable designs, concentrating on the desire to design buildings that adjust themselves to life, and keep modifying their shapes by the rotation of each floor separately, so the same form of the building is not seen twice. Here the dynamic form is based on the traditional 3D design meets a fourth dimension: "Time" which is considered the most powerful dimension of life (Swapnika, 2019). It is clear from the above information that: the previous architectural studies did not provide a clear and comprehensive measure defining levels of achieving sustainable designs, as well as, the implied knowledge and intersections to certain levels and their achievement, which gave special attention to study for their activation in the contexts of design tasks. Therefore, the research problem has emerged by the unclear definition of the levels of sustainable designs achievement in both of the traditional and contemporary architecture. Research objective has determined by identifying those levels in both of the traditional and contemporary architecture. Research methodology, firstly, establishes a theoretical framework consisting the definitions of the primary and secondary vocabularies of these levels and secondly, applied the levels of sustainable designs achievement in architecture on a sample, consisting a range of global contemporary projects which adopted the concept to determine the pattern of the level of sustainability achieved in their designs, reaching the final conclusions, thirdly.

\section{The Theoretical Frame of the Levels of Sustainable Designs Achievement in Architecture}

The first step to solve research problem is establishing and defining the levels of sustainable designs achievement in each of the traditional and contemporary architecture, which have been drawn from the specialized architectural studies trying to learn all design aspects, at the urban and design levels.

Volume 6, Issue 1; June, 2020 


\subsection{Levels of Sustainable Designs Achievement in Traditional Architecture}

It has been found that sustainable designs achieved in the traditional architecture within four levels defined the basic vocabulary of the research topic, which, in turn associated with secondary ones represented by each of the following:

The first Level: Concerning the urban fabric containing it.

The second Level: Concerning the intellectual and design trends based on it.

The third level: Concerning the design elements of the architectural and constructional types employed in.

The fourth level: Concerning design elements treatments.

\subsubsection{Level of Sustainable Designs Achievement in Urban Fabric}

Sustainable designs on the level of the urban fabric of the traditional cities identified by a group of vocabulary related to the nature of the fabric and the pattern of space composition of the units. With regard to the nature of the urban fabric, the compact fabric of traditional Arab cities represents the best example of the application of the concept of sustainability at the level of the city as a whole (Fig. 1), and city planning and processors of movement routes in terms of form, length, orientation, and change of direction represented the basic stage to adapt to the environment, where the compact fabric helped to soften the effects of the harsh climate and high temperatures, dusty and warm wind, solar radiation, affecting the interfaces of its buildings. The positive aspects of the environmental performance of the compact urban fabric is the creation of various places in pressure to help a natural air move between multiple spaces within traditional dwellings. The planning principles for this type of organization consist of a group of housing units with a central courtyard clustered in a tangled web of organic movement confines alleys and narrow winding paths surrounded by semi-solid and shady walls, work with courtyards as thermal regulator for these residential neighborhoods and the city as a whole. (Shaheen \& Al-Zubaidy, 2003). Also, the shading is considered as the most important principle of traditional town planning and rationalization of electrical energy, contributed in saving energy by $30 \%$, and offers aesthetic touches in the city (Thwainy, 2008).

With regard to the special composition patterns of traditional architecture, as one of the criteria of achieving sustainability, where the diversity of neighborhood unit represented in its special organizations, from differences in size, area and the number of housing courts, is one of the patterns of space composition, which seeks to build self-sustainable complexes, a principle which was adopted in the traditional Arab cities (Fig.2) (Schoenauer, 2000). 


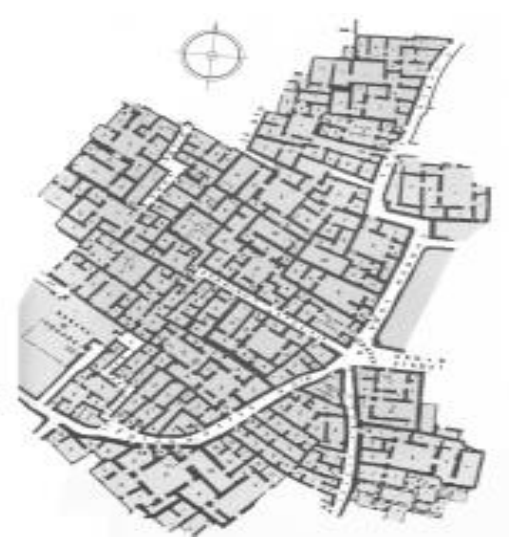

Figure 1: The compact urban fabric (Warren \& Fathi, 1982)
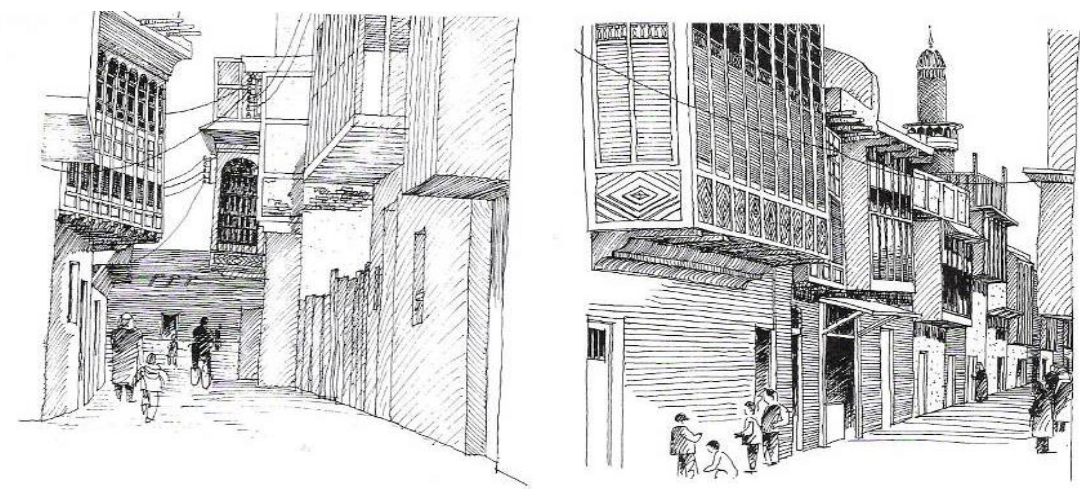

Figure 2: the proximity of housing units and the shading of the movement paths in alleys in Arabic Cities (Schoenauer, 2000)

\subsubsection{Level of Sustainable Designs Achievement in Intellectual and Design Trends}

This level concentrated on two vocabularies, the intellectual trends of original design, and the intellectual trends of environmental design. With regard to the vocabulary of the original design, previous studies have linked between the traditional architecture and constructional thought, to learn how to build in the future (Gissen, 2003). The defenders of sustainability believe that intellectual orientations of the traditional communities embraced the principles formed its strong basis, for example, the use of the open central courtyard as the central point of the orientation toward the inside (introversion), (Fig. 3,4) which formed the important design principles in various civilizations, despite the differences in cultural and natural environments. This stems from the ability to achieve a lot of cultural, aesthetic, social and environmental requirements, such as privacy and protection (Fig.5) (AlZubaidy, 2001). This principle has represented the most efficient design solution for housing in many Arab countries like Syria, Jordan and Egypt, and then with converting them to roofed courtyards, creating an integrated climatically system to maintain power.

Another idea of the original design, is building underground (Fig.6) to exploit the potential of the soil, as the thermal storage block, and the construction adopted built entirely under the ground to reach the thermal comfort and cooling of the interior spaces, such as (Syrdab) in the traditional architecture of the residential areas in Iraq and in most parts of the Arab world (Shaheen\& Al-Zubaidy, 2008; Ragette, 2003). 


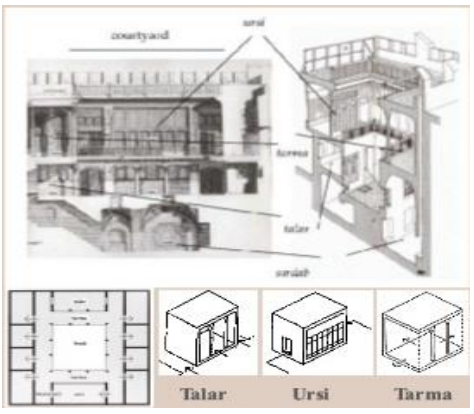

Figure 3: Iraqi Traditional courtyard house (Haraty, 2015)

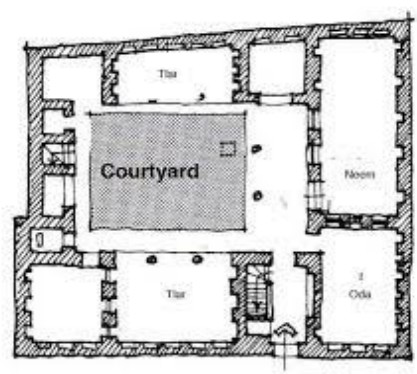

Figure 4: The courtyard, house core to lit \&ventilation (Baiz \& Fathulla, 2016)

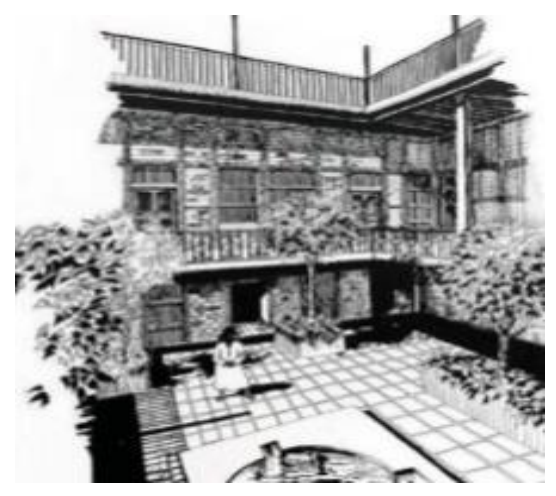

Figure 5: Arch. Elements inside court (Haraty, 2015)

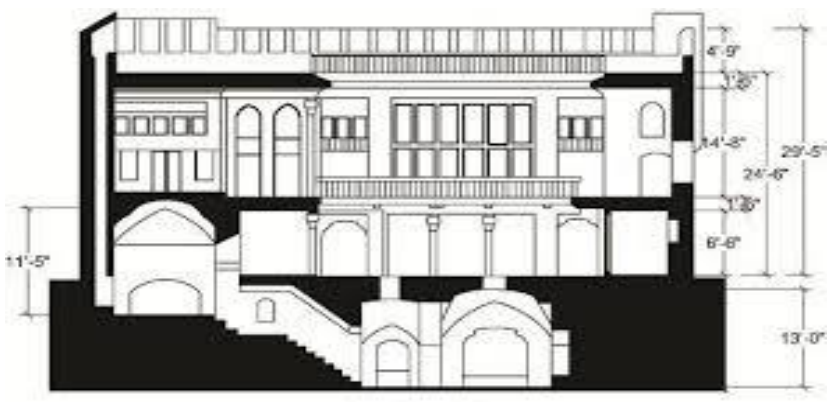

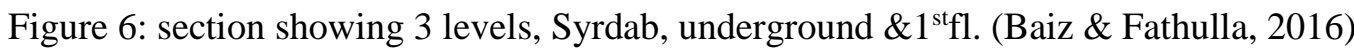

The other principle is the preservation of the environment from pollution was reversed through thoughtful designs of water pipelines and sewerage discharges with its location according to living spaces was to allow the disposal of waste without affecting the environment or public health, with the 
prevailing wind direction, taking into account the disposal of unacceptable odors (Shaheen \& AlZubaidy, 2008).

With regard to the ideas of environmental designs, emerged the idea of (the exploitation of Passive energy), where its design principles and construction materials used in order to provide a comfortable internal environment, achieving sustainability through balanced interaction with the natural resources of the solar, wind, site topography and construction materials, as well as harmonization with social values, customs and traditions of society.

Other ideas of environmental design are developing environmental elements, such as the thermal regulation of courtyard, (Fig. 7), (Thwainy, 2008), which is used for natural ventilation, and becomes like thermal chimney, where cool air moves through the holes in the walls of the alleys to the central courtyard and the interior spaces. In the evening hours and night, when residents use rooftop for seating and sleeping, the courtyards and thick walls start showering the heat stored during the day to clear sky quickly, then, cold air gradually falls down to collect in the courtyard, and this is called night discharge. (Shaheen \& Al-Zubaidy, 2008).

The provision of natural ventilation, through slots of the air or Malkaf, to get rid of excess heat and providing fresh air, is one of the main principles of environmental design, in the traditional patterns, for cooling the human body (Edward \&Torrent, 2000).

\subsubsection{Level of Sustainable Designs Achievement in Architectural Design and Constructional Elements}

Included: design elements invested for the purposes of achieving sustainability in traditional architecture, some of them are architectural elements centered around each of the designed and natural, while other dealt with the structural elements, which in turn centered around both; elements related to the structure and other related to materials used.

The traditional architecture designed innovative architectural elements for natural ventilation like Malkaf or Badgare (Fig.7): which is a slot antenna, with the direction of the prevailing wind, devoted to seize the cold air passing over the building and pushed inside after purified, by composing different pressure regions between the inside and outside.

Other architectural elements like Fountains, (Fig.8), placed at the center of the courtyard, giving aesthetics and comfort, either, Salsabeel is the wavy marble plate inspired by the wind or water and put into the aperture in the wall, to allow water to drip over its surface to increase the moisture in the air, and Iwan is the shaded roof hall with only three walls overlooking the courtyard and headed by arcade and perhaps contacted multiple halls. There is also Shakhshakhena or skylight used in the coverage of the main halls to provide indirect ventilation and lighting for the hall. The decorative architectural elements employed for environmental purposes, as Shanasheel or Mushrabia (Fig.9,10,11) were designed as wooden network screen with geometrically ornamental form, set the air, light and provided privacy (Thwainy, 2008). The studies included a range of natural design elements in the traditional architecture such as water, where it had a big role in alleviating the harsh climatic conditions, especially in hot dry climate zones. The green surfaces and plants (Fig.8) are strategies to provide comfortable interior environment and work as filters to rid the outside air from dust and sand particles, lowering its temperatures. 
On the level of the structural elements of the traditional architecture, it has been all of the roofs and walls forming the building envelope, which was the barrier between the inside and the outside, and composed of various building materials (Shaheen\& Al-Zubaidy, 2008). Also the form of building envelope (the roofs and walls) played an important role with energy consumption, especially the vaulted roofs with half dome, or half shaded cylinder, which always increase the speed of the air passing over their curved surfaces, reducing the temperature of the ceiling (Al-Khouly, 1975).

Traditional architecture employed local building materials, with simple studied techniques stemming from the local environment and the resources available. These materials possessed great importance in achieving sustainability such as brick, stone, gypsum and palm trunks, which were efficient in reducing energy consumption and providing cost-effective, without causing a negative impact on the environment (Shaheen \& Al-Zubaidy, 2008).
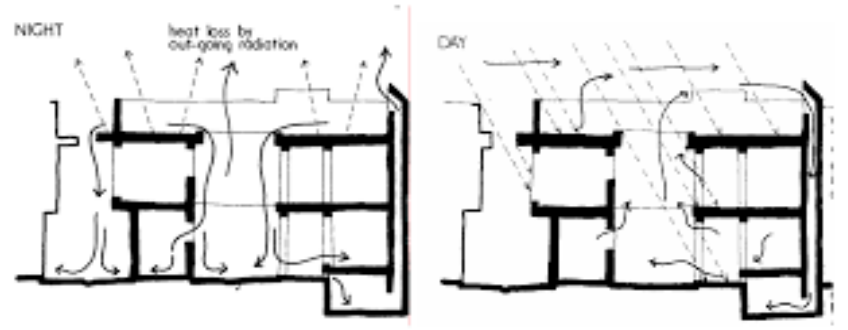

Figure 7: Day and night thermal organization in the court house (Baiz \& Fathulla, 2016)

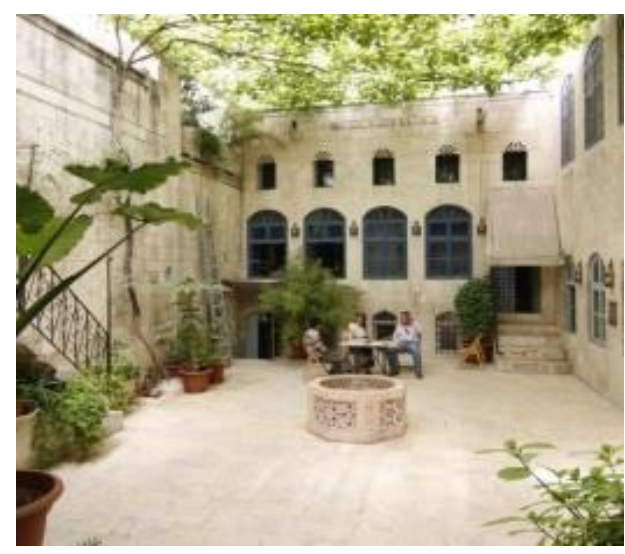

Figure 8: Fountains and green areas (Abbis, 2008)

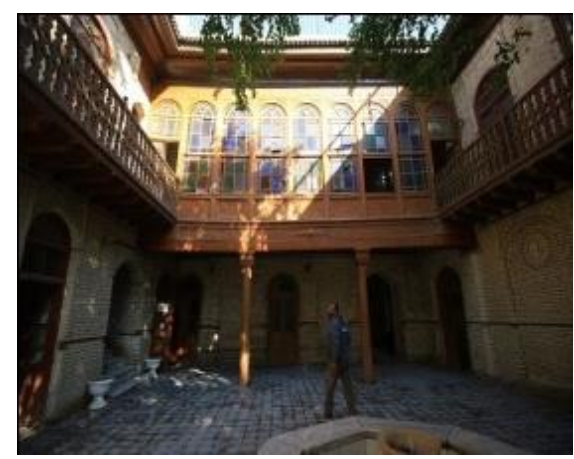

Figure 9: Shanasheel (Jameel, 2018) 

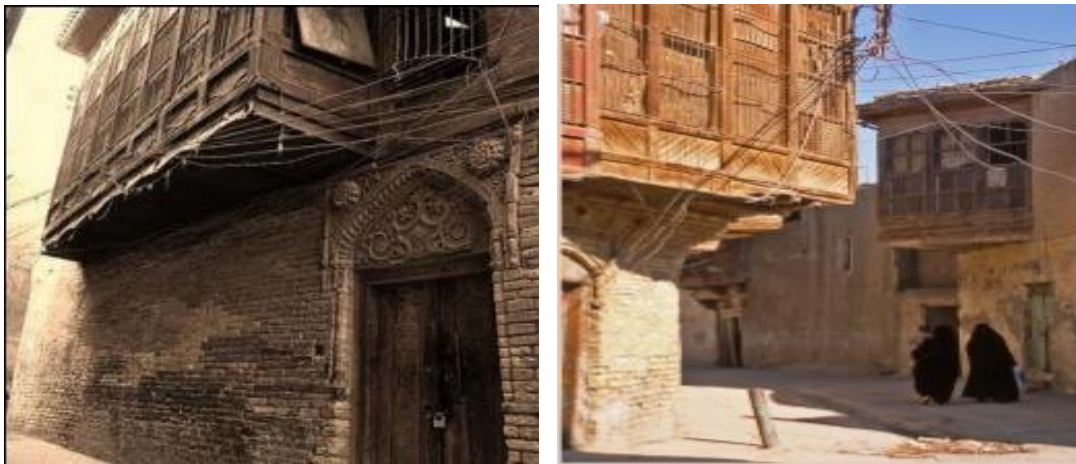

Figure 10 \& 11: Mushrabia (Haraty et al., 2018; Haraty, 2015)

\subsubsection{Level of Sustainable Designs Achievement in Design Treatment of Elements}

This level covered the physical procedures ongoing process on key design elements, and they were centered on two vocabularies, the first linked to processors on the structures, whereas the second associated with natural processors. With regard to processors on the traditional buildings envelope (the walls and roofs) to reduce the thermal energy to the internal spaces, thus reducing energy consumption, are as follows:

1. The top surface of the roofs, and the external walls were even covered with reflective materials to get rid of solar radiation like metal panels or finished with pristine white color.

2. Air void insulator was left between the two layers of the roof as a vacuum. As well as the optimal use of the voidable or double walls.

3. Move the hot air gathered on the bottom of the roofs by small holes placed bottom or close to it

4. Covering the bottom surface of the roofs projecting outside walls, with a darkening absorbent of solar rays.

5. Forms of dome and vault we reemployed in this Arabic climatic region because of the aspect of curved surfaces, to not fully be exposed to sunlight, unlike to the horizontal surfaces.

6. Walls openings were provided with sun breakers for shading and reducing glare in the interior spaces.

On the level of the natural, processors, it was presented by offering natural elements near buildings, as green surfaces and adjacent water areas, with pools and evergreen trees (Al-Khouly, 1975).

To conclude, the ideological orientation of the ancient civilization and the traditional communities embraced the ideas and principles stemming from the identity, which formed a strong basis for sustainable architecture known today and that the roots of this architecture can be followed by long years through the ages, where the available resources including land, water and local building materials, were exploited with high efficiency, as well as creative environmental processors have contributed largely to the creation of an environmental compatibility between its buildings and surrounding environments, where achievements in the past local architecture, represented models and early applications of the concept of green architecture and sustainable development (Table 1).

Thus, the four levels of sustainable designs achievement in the traditional contexts, learned in this research area, enhanced attention of their employment in the contemporary architecture that are compatible with the needs of the age of scientific and technical progress in systems and building materials. 


\subsection{Sustainability in Contemporary Architecture/Levels of Sustainable Designs Achievement in Contemporary Architecture}

Attention began with the concept of sustainable architecture since the beginning of the 1970s, that focuses on three basic dimensions (the environmental - Social - Economic) to achieve the requirements of the societies, and as a reaction to shortage of natural resources, (Selim, 2011), as well as, the wide spread of cubic buildings surrounded by glass and steel which requires enormous heating and expensive cooling systems, and here each of the Architects Fall, Fox, Foster, Rogers, and Fisher started the exploration of architectural designs, which focused on the long-term environmental impact during the performance and maintenance of the buildings. In this regard, emerged new concepts and methods not familiar in the design and implementation of projects, such as green and dynamic architecture, all of which reflected the growing interest in the protection of the environment, reduce energy consumption and depending on renewal energy resources and clean energy production (Tanta University, 2011).

This also leads to design sustainable buildings which are friendly to environment having the ability to be self- energy using it in the operation of the building itself, by the introduction of the concept of change and movement within the "time unit", for parts of the building (elevations, roofs and floors) or levels or even the building as a whole in response to the surrounding circumstances, moving the building up to a new performance level, changing the design process to $4 \mathrm{D}$, to show the enormous potential of technology, as Fischer called:" it is an architecture of formation of life and the design of time" (Mohammad, 2015).

According to previous studies, the levels of achieving sustainability in contemporary architecture, included the exploration of two others, added to the four levels referred to previously in traditional architecture, as well as the exploration of some secondary vocabulary involving within the second level associated with the intellectual and design trends. Thus the classifications for the levels in contemporary architecture as the following:

The first Level: Concerning the urban fabric containing it.

The second Level: Concerning the intellectual and design trends based on it.

The third level: Concerning the design elements of the architectural and constructional types employed in.

The fourth level: Concerning the design elements treatments.

The fifth level: Concerning the performance aspects of the building.

The sixth level: Concerning the humanitarian aspects associated with.

Research is limited to discussing the latest knowledge in the added levels of contemporary architecture, for the fact that other levels had been covered in the previous paragraphs of the traditional architecture, as most levels are considered as continuous from that of precedent as the architect Foster in the Re Swiss Tower, London, described, that his rich background of precedent was, behind his high-tech approach especially the idea of passive energy of downward-moving air cooling the spaces, dates further back to the wind towers of traditional Middle Eastern architecture (mattJohnsonarchitecture.wordpress.com, 2014). 
With regard to the level of sustainability achievement of the intellectual and design trends, the vocabulary represented by: the intellectual trends of both, the original design, and the environmental design, plus the vocabulary of the intellectual trends for sustainable building itself.

With regard to the intellectual trends of sustainable building itself, previous studies, pointed out, to the principle of respect for the site, using methods of design ideas that would cause the least changes possible in construction sites, especially, drilling and reclamation works or grab the trees. In this regard, emerged the project of the dynamic structural system tents to accommodate and shelter the pilgrims in Mina Valley, and totally consistent with the nature of its location, keeping the environment and the topography of the site. In the same context, highlighting the principle of rehabilitation, that means, to use buildings for other functions and activities, and to reduce the use of new resources (Thwainy, 2008). Studies also pointed out a group of principles and ideas, which are essential to achieve sustainability in contemporary buildings like: growth capability, flexibility, and future extension, reuse, rehabilitation, historic preservation, energy self-sufficiency, achieving the maximum investment of energies, the overall design by the integration of all the principles of sustainable architecture on both levels: building design and city planning, with implying sustainable building, all elements of creativity (www.arab-eng.org, 2008).

\subsubsection{Level of Sustainable Designs Achievement of the Building Performance Aspects}

Associated with the rapid technical developments in the third millennium, exploring innovative new levels of performance, like using less energy as in the Gherkin skyscraper, Norman Foster, London, (Fig.18 ) using 50\% less energy than the traditional office building because of the performance of its double insulating envelope of glass panels and innovative application of age-old passive design methods, with the six vertically open atria that channel fluid dynamic of cool air down, allowing natural light to penetrate (mattJohnsonarchitecture.wordpress.com, 2014). Another performance level, in which the environmental, technical and implementation aspects integrated with the formation aspects, utilizes the building to the dynamic state, by the movement of: a-interior parts (as interior smart movable furniture and walls) or b- exterior parts of the building with (dynamic elevations): as in "Kiefer showroom" building, (Fig. 12), where the elevation is changing its external form in more than one pattern in one part or the whole elevation according to external environment, angles of the sun, desire to the openness to outside.
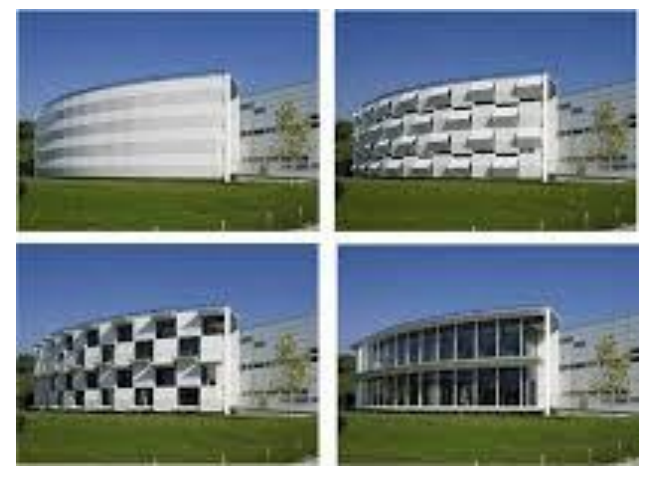

Figure 12: Kiefer showroom" building, Austria,Graze 


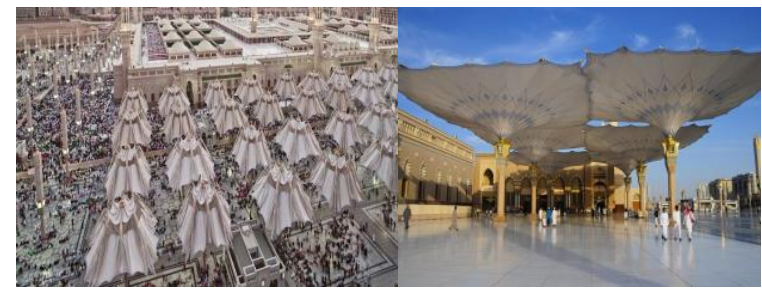

Figure 13: The expansion coverage of the Prophet's Holy Mosque in Madina, 2010. (alfozanaward.org /2011) (designlike.com, 2013)

Or (the movement of roofs, dynamic coverage) to change the external and internal form constantly, offering shaded areas to protection from sun rays and the use of natural ventilation according to the weather, for e.g.: the expansion of the coverage of the Prophet's Holy Mosque in Madina, Saudi Arabia, SL-Rasch with SEFAR AR., 2010 (fig.13) .Or the movement of some building levels (dynamic levels) as a kind of aesthetic appearance in viewing the external environment, for e.g.: CN tower in Canada, 1976, where its upper floor ends with movable restaurant which rotates 360 around itself, (Fig. 14) (Mohammad, 2015).
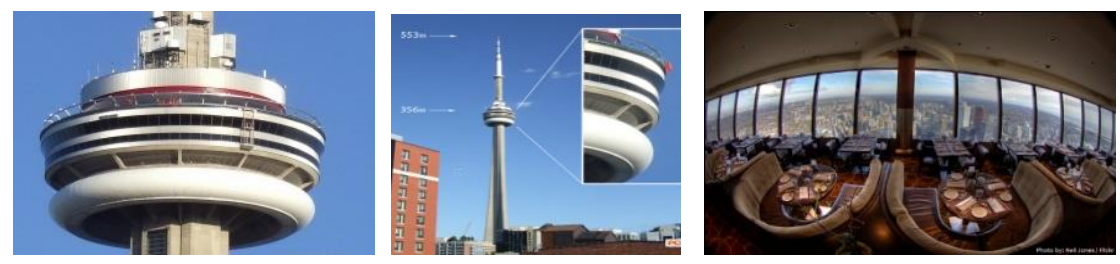

Figure 14: CN tower in Canada, 1976, with movable restaurant (en.m.wikipedia.org, 2019)

And finally (the movement of the building as a whole) to rotate around itself within a unit of time, changing its form continuously, to achieve convenience with the environment and with human imagination, and functions as "a machine for living" according to dr. Fisher's vision, so the man for the first time, will have a building in four dimensions (time). These sustainable rotating buildings will be so smart to produce enough power via its wind turbines and external photovoltaic panels for themselves and to sell the excess to the city around them (www.designbuild-network.com, 2019). Example about that is Da Vinci Rotating Tower, Dubai, for David Fisher, 2008-2020, (Fig. 15), which adopts three innovative performance concepts, the first of, is dynamic by changing its shape continuously within a unit of time, and the second, is green by self-production of clean energy used in the movement of the building, while the third is the clean construction method due to industrially produced prefabricated modules, therefore, be more efficient and environmentally friendly building with cost and construction time saving, and sites will become smart ones, and safer with less waste materials, and noise (Swapnika, 2019).

\subsubsection{Level of Sustainable Designs Achievement of the Humanitarian Aspects of the Building}

This level is depended on the users of the buildings, including two vocabulary covering both, preventive sustainability and participatory sustainability. Studies covered a range of preventive issues, concentrated on the respect of the building users to environment by reducing the negative effects of buildings and cities' designs, the consumption of energy and resources, pollution and the use of new and renewable energies to provide clean energy. 
The employment of robots to implement some of the dangerous work instead of human being in construction, as in Japan to ensure the health of the workers, as well as emphasis on Safety Factors like finishing materials and quality construction operations to respond to environmental disasters, such as hurricanes, earthquakes and fires. Other preventive issues, are using natural construction materials which preserve the human environment from destruction, as the use of timber without destroying forests, and recycling residues and the remnants of the buildings (Thwainy, 2008).

With regard to the participatory aspects, presented the importance of the integration of the design environment, depending on the cooperation of all specializations participating in sustainable designs with the assessment of decision-making, and the participation of users and local communities. So sustainable designs always require the integration of environmental, innovative, social, traditional, political and ethical values with the users' expectations and technology (www.arab-eng.com, 2008). (Table1).

Table: 1 Levels of achieving sustainability in traditional and contemporary architecture

\begin{tabular}{|c|c|c|c|c|c|c|c|}
\hline \multicolumn{2}{|c|}{$\begin{array}{l}\text { Type of } \\
\text { architect } \\
\text { ure }\end{array}$} & \multicolumn{2}{|c|}{$\begin{array}{l}\text { Levels of } \\
\text { achieving } \\
\text { sustainable } \\
\text { designs }\end{array}$} & Main vocabulary & values & & \\
\hline \multirow{7}{*}{ 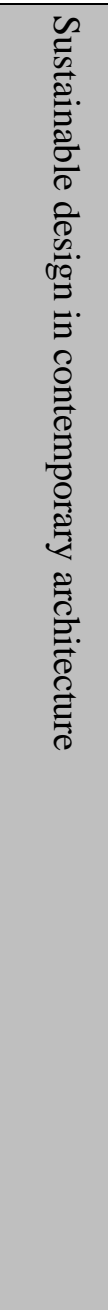 } & \multirow{7}{*}{ 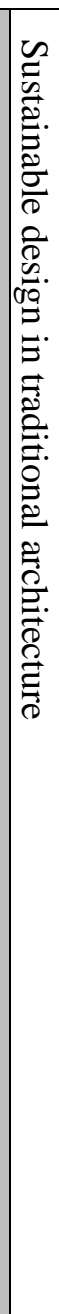 } & \multirow{2}{*}{1} & \multirow{2}{*}{$\begin{array}{l}\text { The urban } \\
\text { fabric } \\
\text { containing } \\
\text { it }\end{array}$} & Fabric nature & \multicolumn{3}{|c|}{$\begin{array}{l}\text { Compact fabric, organic movement with } \\
\text { alleys, semi solid and shaded walls. }\end{array}$} \\
\hline & & & & $\begin{array}{l}\text { Units space } \\
\text { organization } \\
\text { pattern }\end{array}$ & \multicolumn{3}{|c|}{$\begin{array}{l}\text { Clustered housing units with courtyards, } \\
\text { diversity of neighborhood unit in(size, } \\
\text { area, no. of housing courts) }\end{array}$} \\
\hline & & & \multirow{5}{*}{$\begin{array}{l}\text { The } \\
\text { intellectual } \\
\text { and design } \\
\text { trends } \\
\text { based on }\end{array}$} & \multirow[t]{2}{*}{$\begin{array}{l}\text { The intellectual } \\
\text { trends of original } \\
\text { design }\end{array}$} & \multicolumn{2}{|c|}{$\begin{array}{l}\text { Introversion } \\
\text { toward } \\
\text { central } \\
\text { courtyard }\end{array}$} & $\begin{array}{l}\text { Open court } \\
\text { Roofed court }\end{array}$ \\
\hline & & 2 & & & \multicolumn{3}{|c|}{$\begin{array}{l}\text { Preservation from pollution (location and } \\
\text { design for water pipes and sewerage } \\
\text { discharge. }\end{array}$} \\
\hline & & & & \multirow{3}{*}{$\begin{array}{l}\text { The intellectual } \\
\text { trends of } \\
\text { environmental } \\
\text { design }\end{array}$} & \multirow[t]{2}{*}{$\begin{array}{l}\text { Passive } \\
\text { energy } \\
\text { system }\end{array}$} & \multicolumn{2}{|c|}{$\begin{array}{l}\text { Natural resources (wind, sun, } \\
\text { site topography), }\end{array}$} \\
\hline & & & & & & \multicolumn{2}{|c|}{ construction materials } \\
\hline & & & & & \multicolumn{2}{|c|}{$\begin{array}{l}\text { Thermal } \\
\text { regulation of } \\
\text { open central }\end{array}$} & Natural ventilation \\
\hline
\end{tabular}




\begin{tabular}{|c|c|c|c|c|c|}
\hline & & & \multicolumn{2}{|c|}{$\begin{array}{l}\text { courtyard } \\
\text { surrounded by } \\
\text { thick walls and } \\
\text { narrow shaded } \\
\text { routes }\end{array}$} & \\
\hline & & & \multicolumn{2}{|c|}{$\begin{array}{l}\text { Central open } \\
\text { court, ,atrium }\end{array}$} & Natural lighting \\
\hline & & & \multicolumn{3}{|c|}{ Roof top as sitting and sleeping area. } \\
\hline & & $\begin{array}{l}\text { the intellectual } \\
\text { trends of } \\
\text { sustainable } \\
\text { building itself }\end{array}$ & \multicolumn{3}{|c|}{$\begin{array}{l}\text { respect the site, growth, flexibility, } \\
\text { extension, energy self-sufficiency, reuse, } \\
\text { rehabilitation, overall design, creativity } \\
\text { and preservation. }\end{array}$} \\
\hline \multirow[t]{6}{*}{3} & \multirow[t]{6}{*}{$\begin{array}{l}\text { the design } \\
\text { elements } \\
\text { of } \\
\text { architectur } \\
\text { al and } \\
\text { constructio } \\
\text { nal types } \\
\text { employed } \\
\text { in }\end{array}$} & \multirow[t]{2}{*}{$\begin{array}{l}\text { The architectural } \\
\text { elements }\end{array}$} & $\begin{array}{l}\text { The } \\
\text { designe } \\
\text { d } \\
\text { element } \\
\text { s }\end{array}$ & \multicolumn{2}{|c|}{$\begin{array}{l}\text { Courtyard, Iwan (shaded } \\
\text { roofed semi opened sitting } \\
\text { area, shakhshakhina } \\
\text { (skylight), mushrabia or } \\
\text { shanasheel (ornament, provide } \\
\text { light and air, privacy, prevent } \\
\text { glare), fountains and } \\
\text { salsabeel, malkaf or } \\
\text { badgare(natural ventilation) }\end{array}$} \\
\hline & & & $\begin{array}{l}\text { The } \\
\text { natural } \\
\text { element } \\
\mathrm{s}\end{array}$ & \multicolumn{2}{|c|}{$\begin{array}{l}\text { Water, green plants and } \\
\text { surfaces (filters, cool air and } \\
\text { lowering temp.). }\end{array}$} \\
\hline & & \multirow{4}{*}{$\begin{array}{l}\text { The structural } \\
\text { elements }\end{array}$} & \multirow{2}{*}{$\begin{array}{l}\text { Building } \\
\text { envelop } \\
\text { e }\end{array}$} & \multicolumn{2}{|c|}{ Roofs (vaulted, half dome) } \\
\hline & & & & \multicolumn{2}{|c|}{ Walls (thick semi solid) } \\
\hline & & & \multirow[t]{2}{*}{$\begin{array}{l}\text { Building } \\
\text { material } \\
\mathrm{s}\end{array}$} & \multicolumn{2}{|c|}{$\begin{array}{l}\text { Local building } \\
\text { materials(brick, mud, gypsum, } \\
\text { stone, palm trunks) }\end{array}$} \\
\hline & & & & \multicolumn{2}{|c|}{ Simple techniques } \\
\hline \multirow{3}{*}{4} & \multirow{3}{*}{$\begin{array}{l}\text { The design } \\
\text { treatments }\end{array}$} & \multirow{3}{*}{$\begin{array}{l}\text { Processors on the } \\
\text { structure or } \\
\text { building }\end{array}$} & \multicolumn{3}{|c|}{$\begin{array}{l}\text { Roofs covered with reflective materials } \\
\text { like metal panels. }\end{array}$} \\
\hline & & & \multicolumn{3}{|c|}{ Finished with pristine white color. } \\
\hline & & & \multicolumn{3}{|c|}{$\begin{array}{l}\text { Air void insulator between two layers of } \\
\text { construction for roofs. }\end{array}$} \\
\hline
\end{tabular}




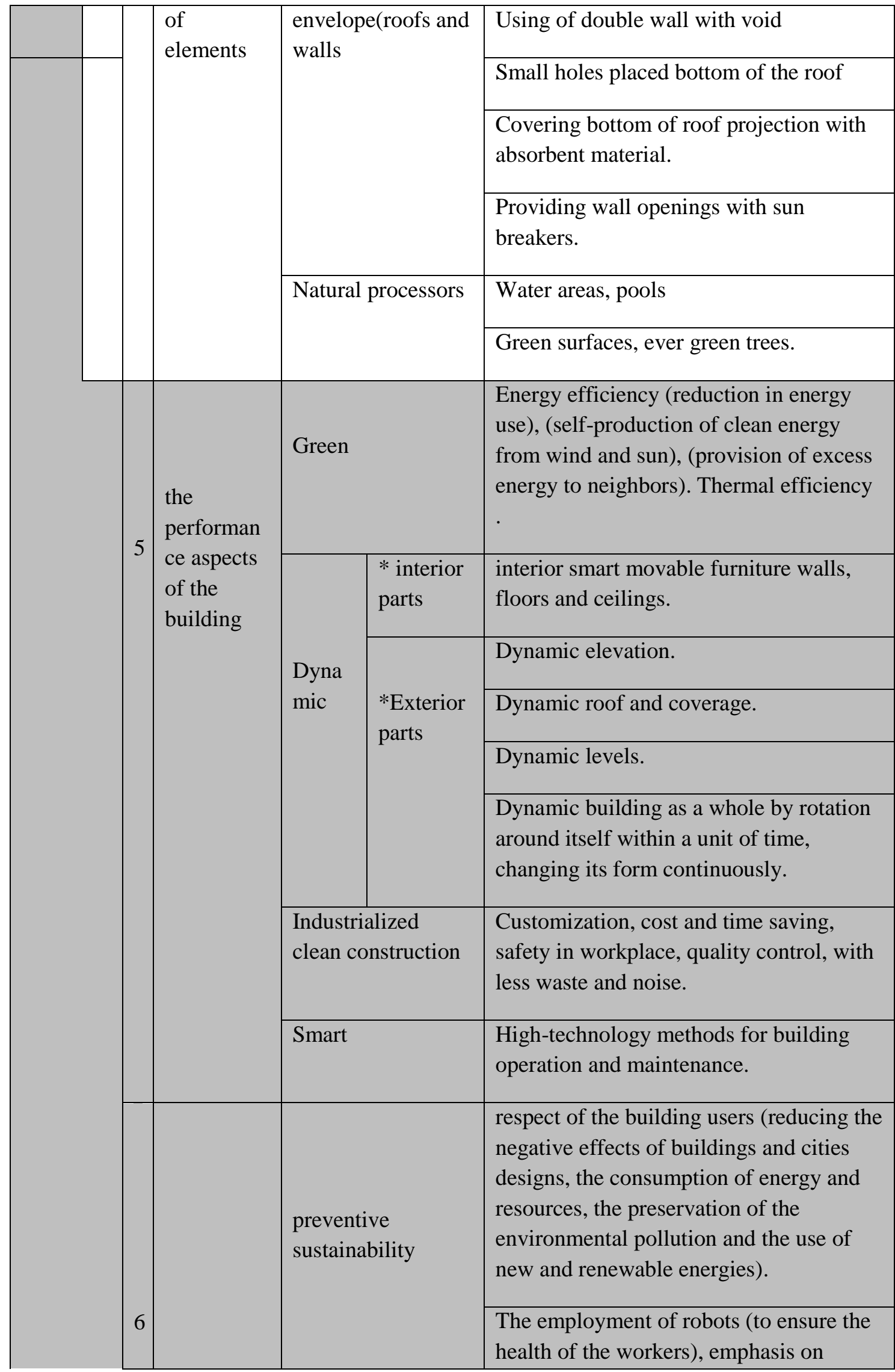




\begin{tabular}{|l|l|l|l|}
\hline \multirow{2}{*}{\begin{tabular}{l} 
the $\begin{array}{l}\text { humanitari } \\
\text { an aspects }\end{array}$ \\
\cline { 2 - 3 }
\end{tabular}} & $\begin{array}{l}\text { participatory } \\
\text { sustainability } \\
\text { materials, recycling residues }\end{array}$ \\
\cline { 2 - 3 } & $\begin{array}{l}\text { the integration of the issues of the design } \\
\text { environment with the users' expectations } \\
\text { and technology, the participation of users } \\
\text { and local communities }\end{array}$ \\
\hline
\end{tabular}

w $\square$ white spaces are the 4 levels of achieving sustainability in traditional architecture, where as white $\square$ +gray $\square$ spaces are the 6 integrated levels of achieving sustainability in contemporary architecture), (authors).

\section{The practical Applications of the Levels of Sustainable Designs Achievement in Contemporary Architecture}

The second step to solve research problem is to apply those levels of sustainable designs achievement with their vocabularies on a sample consisting a range of global projects (6 products), which adopted the concept according to the extensive explanations in the context of theoretical studies, to determine the pattern of the level of sustainability achieved in their designs.

\subsection{Descriptions and Analysis of the Projects in Progress}

\subsubsection{The Dynamic Tower or Da Vinci Tower/ D. Fisher, Dubai, UAE/2008-2020}

Description: It is a proposed 420-metre, 80-floor moving skyscraper, each floor is designed to rotate independently one full rotation in 180 minutes, resulting in a changing shape of the tower. (Wall Street Journal, 2008). It is similar to the Suite Vollard completed in 2001 in Brazil (Randl, 2008). The entire sustainable tower is proposed to be powered from wind turbines and solar panels. Enough surplus electricity should be produced to power five other similar sized buildings in the vicinity. The horizontal turbines would be located between each of the rotating floors and the solar panels are expected to cover the roof and the top of each floor (Emporis.com , 2008). It was the world's first prefabricated skyscraper with 40 factory-built modules for each floor, and $90 \%$ of the tower could be built in a factory allowing the entire building to be built more quickly. The core of the tower only must be built at the construction site, and thus the prefabricated portions would decrease the project's cost, time and the number of workers working under safer conditions.

This Dynamic tower which based functionally on a combination of a hotel, villas and apartments, restaurant and office tower, reveals three major innovations: changing shapes, clean construction method by the industrial production of units and self-production of clean energy. So modern architecture will not more confined to rigid static forms and construction will have a new approach and flexibility (www.busyboo.com, 2007).

Analysis : The previous proposition implies most of the levels that have achieved sustainability: as the level of the intellectual and design trends, (the original design trends: with the values of dynamic principle of movement adding the fourth dimension of (time)to design process, also (the trends of the environmental design by employing solar panels and wind turbines to produce energy) and (the trends for sustainable building itself as flexibility, energy self-sufficiency, creativity), also the level of the structural elements, as the industrialized modular units having a special treatment for each floor that 
pinned to central core). Also a concentration on the level of building performance aspects with the values of (dynamic movement of the tower as a whole, green or self-producing energy with providing the excess to neighbors, prefabricated and smart) Then, the special level of the humanitarian aspects with the vocabulary of offering some preventive issues, like safety factors.
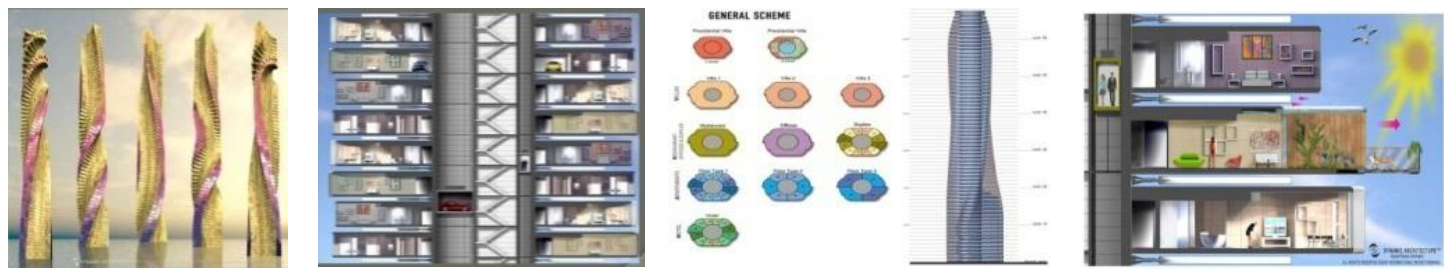

Figure 15: Dubai Tower (Raktim, 2019)

\subsubsection{Conde Nast Building, New York, Fox \& Fowle, 1996- 1999}

Description: It is green design skyscraper, in which environmentally friendly absorption chillers, along with a high-performance insulating and shading curtain wall, ensure that it does not need to be heated or cooled for most of the year, where the air-delivery system provides $50 \%$ more fresh air, and recycling chutes serve the entire building that uses solar technology Pure Cell systems (en.m.wikipedia.org, 2019). The height of this tower is $264 \mathrm{~m}$. with 48 stories, and is considered as the centerpiece of this site, at the intersection of Broadway and 42nd Street, "The Crossroads of the World" excels as a piece of urban theater, with a cluster of neon signs at the base and an eruption of high technology hardware popping out of the top. In this building, all systems and construction technology have been evaluated for their impact on occupant health, environmental sensitivity, and energy reduction, adopting energy conservation, indoor air quality, recycling systems (wired newyork.com 12013). Also, energy consumption was by using of PV solar cells with different forms, used as finishing material, umbrellas for rain or solar breakers (Thwainy, 2008).

Analysis: The above descriptions mentioned, some of the relevant aspects of achieving sustainability, starting from the strong relation to its location as a piece of nature of the urban theater, then the intellectual trends of environmental design (employing high- tech. systems), the level of the architectural and constructional design elements types, like the shading curtain wall and particular types of materials used as( PV solar cells) and the way of design elements treatments, then the performance level as a smart high-tech tower with high performing envelope providing energy reduction and offering preventive sustainability by providing health, pollution and quality control, and recycling systems.
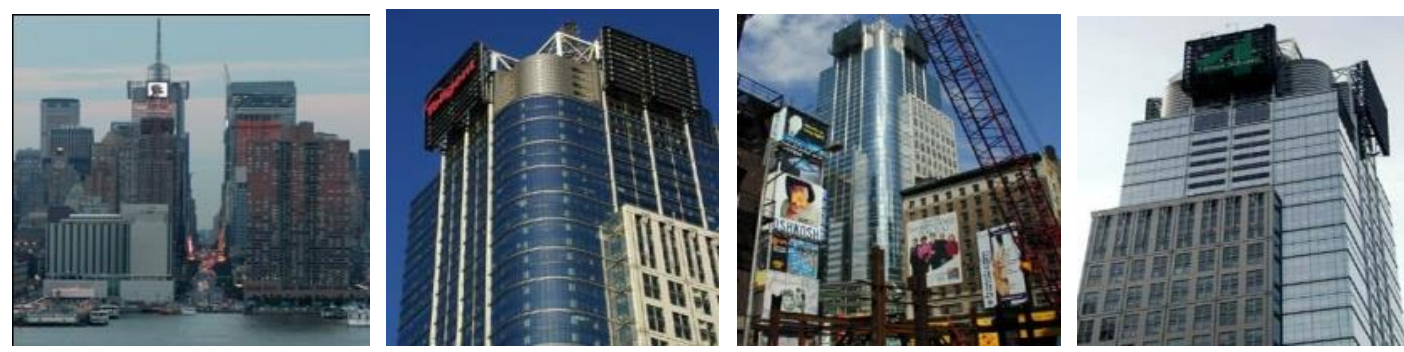

Figure 16: Conde Nast building (wirednewyork.com, 2013) 


\subsubsection{The Green Building of Louisville, Kentucky, USA, (fer)studio, D.Pierson, 2008}

Description: It's the $1^{\text {st }}$ LEED certified adaptive reuse and restoration of the existing building, (a 110year-old former store), which became the hip commercial city center for the arts and sustainability. The principles applied in this building are: 1- Energy efficiency-the Green Building saves 30000 pounds and has 81 solar panels with up to $68 \%$ total off- grid energy efficiency.2-Re-used materialin addition to saving the original mortar shell of the structure, architects re-used much of the material from the original building, like structural wood and bricks, specifying eco-friendly materials.3Recycled material-it contains recycled materials including :the flooring, the windows, and the insulation. 4-Historic preservation in the traditional sense-opting to keep the original masonry shell and façade, architects opened up the space to light by raising the lobby ceiling up to 40ft, adding an insulated glass spine with exterior louvers preventing heat penetration (Alter, 2010). So rehabilitation and recycling the existing building was the ultimate green gesture. 5-Natural ventilation- multi vents are opened to bring fresh air.6-water management-three massive rain barrels capture any overflow from the green vegetated roof, used to irrigate the green roof and garden. 7-Natural lighting-through the ascending glass spine (www.podand.com, 2010).

Analysis: The above information declared concentration on the level related to the intellectual and design trends: the environmental design trends: (energy management, extensive solar power, geothermal wells) and the aspects of sustainable building itself (as adaptive reuse, rehabilitation of the older existing building and reuse of materials, historic preservation, resuscitating the structure, renewable energy systems,). Also, presented the architectural elements (as the insulated glass spine for natural lighting), and constructional elements(as the masonry structural shell, with the eco- friendly building materials, also declared the way of design elements treatments (as the structural shell and infusing it with a modern core)and natural processors(as the vegetated roof), then the performance level presented by(a smart green building creating sufficient energy), and also the preventive issues: (as recycling materials). This building is setting the basis of sustainable designs in traditional architecture that could be continued in contemporary ones.
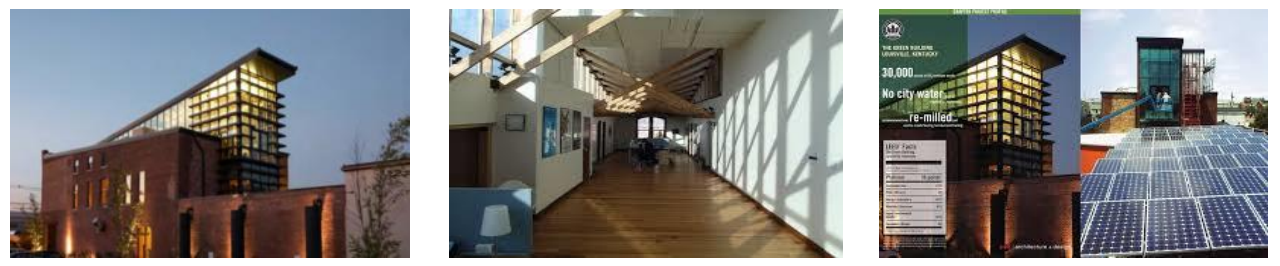

Figure 17: The Green Building of Louisville (www.podand.com, 2010)

\subsubsection{Hearst Tower (Manhattan), New York, Norman Foster, 2006}

Description: It is designed for housing communication companies, with 46 stories, over a 6 story base building, dated to 1928. The original cast stone facade has been preserved in the new design as a Landmark site and the tower rises (182m) from the original plinth, signifying a link between old and new. Hearst Tower is the "green" high-rise office building, with a number of environmental considerations, as (heat conductive limestone atrium floor with embedded polyethylene tubing for cooling and heating, rain collected on the roof is for use in the cooling system, and to irrigate plants, $85 \%$ of the building's structural steel contains recycled material, wide waterfall titled Icefall, which cools and humidifies the 10 story atrium air). Overall, the building has been designed to be $26 \%$ more energy efficient than a standard office one (en.m.wikipedia.org, 2019). The design is defined by the 
use of vertical and horizontal energy-saving, diamond-shaped bands of bright stainless steel on its outside features to create an energy-conserving office environment for employees. The exterior of the new tower is dominated by a 'diagrid' design; consists of recycled steel triangles prefabricated providing the office and plaza areas with natural light. Other energy saving features are (glass coating to reduce solar radiation, motion sensors, few internal walls and partitions to maximize natural light, low-toxicity furniture). The main space of the tower is the grand plaza that has been designed with a full complement of modern technologies (www.designbuild-network.com, 2019).

Analysis: The previous knowledge presents the employment of different levels of achieving sustainability: the intellectual trends related to design and environmental trends( façade preservation, the idea of covered atrium with the giant Icefall, cooling systems), also the level of architectural and constructional elements(the exterior envelope of dia grid steel and glass triangular construction), and the use of materials with different treatments to save energy (coated glass and walls as well as nontoxic furniture and recycled steel). Furthermore, is the level of performance achieved by energy saving envelope and using high technologies. Also, the level of preventive issues by: (offering efficient energy saving offices and natural light, safety factors). This building sets the best link between traditional and contemporary sustainable design.
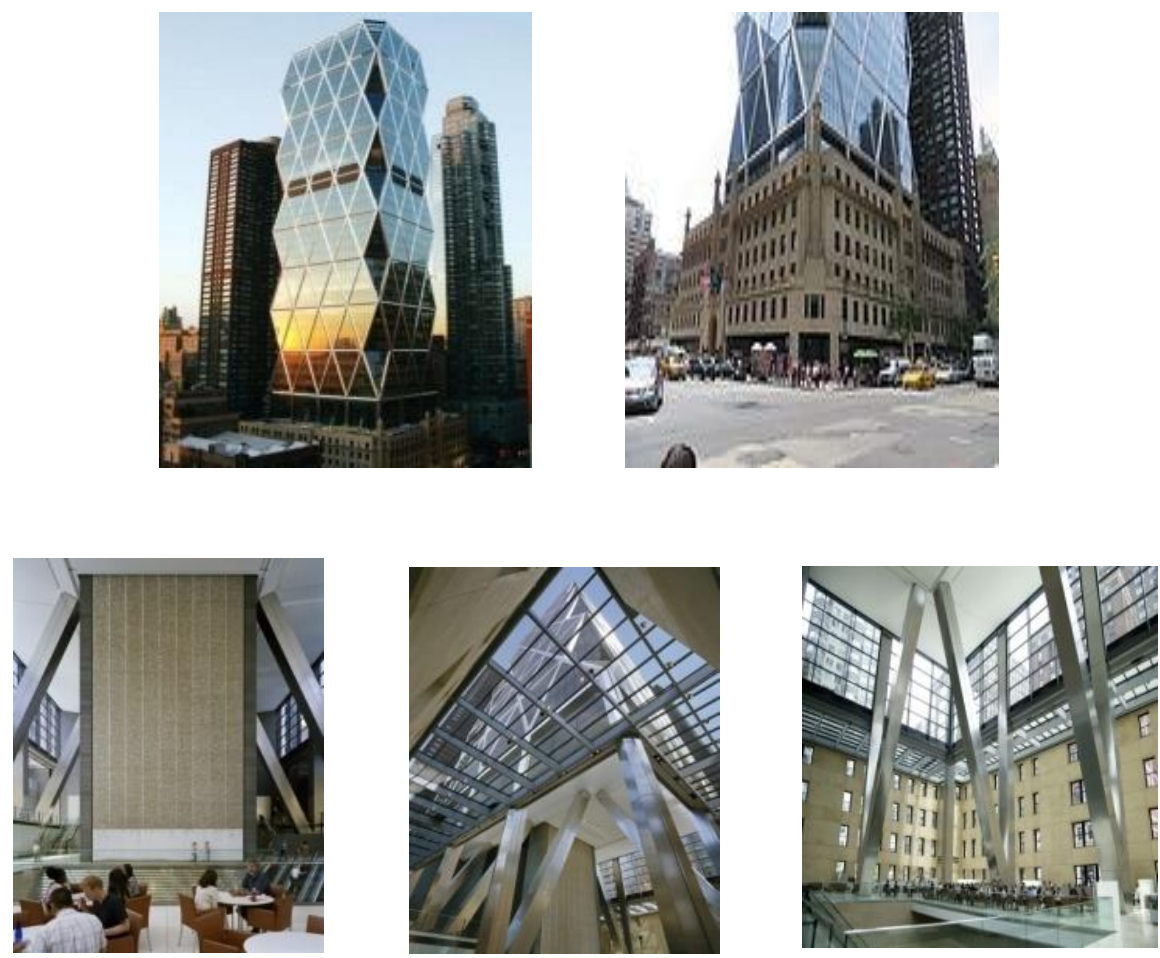

Figure18: Hearst Tower (www.archdaily.com, 2012)

\subsubsection{The Swiss Re Tower, London, Norman Foster, 2004}

Description: This green building with 41 story, celebrated energy efficiency by innovative application of old-age passive design methods. London's first environmental skyscraper uses $50 \%$ less energy than a traditional office. The tower employs a double envelope of glass panels creating a thermal buffer between exterior and interior that has an insulating effect, furthermore, air circulation within the tower 
by six open atria that spiral up all the tower height which channel cool exterior air down and allowing natural light and views to penetrate deeper into the building. Foster innovation was in applying traditional elements at an unprecedented scale.(mattJohnsonarchitecture.wordpress.com, 2014). This building with its ellipsoid shape celebrates the spiraling atria with darker glazing, uniting environmental and aesthetic design which is called by Buchanan (the highest and the truest form of creativity). This tower represents the concept of marrying ancient techniques with cutting age technology which define a hybrid architecture of the new green era. (Buchanan, 2005).

Analysis: The above information clarified the employment of different levels to achieve sustainability especially the intellectual trends of original and environmental design(by the curved shape of the form, using the thermal envelope, and atrium air circulation and passive energy system), also the use of architectural and constructional elements with traditional and smart materials with treatments as(the envelope's double glass panels with void between layers), furthermore, the high performance of the tower(by energy efficiency and fluid dynamic of air circulation through the section of the structure, providing energy reduction), and moreover being smart and creative building linked to traditional ones.
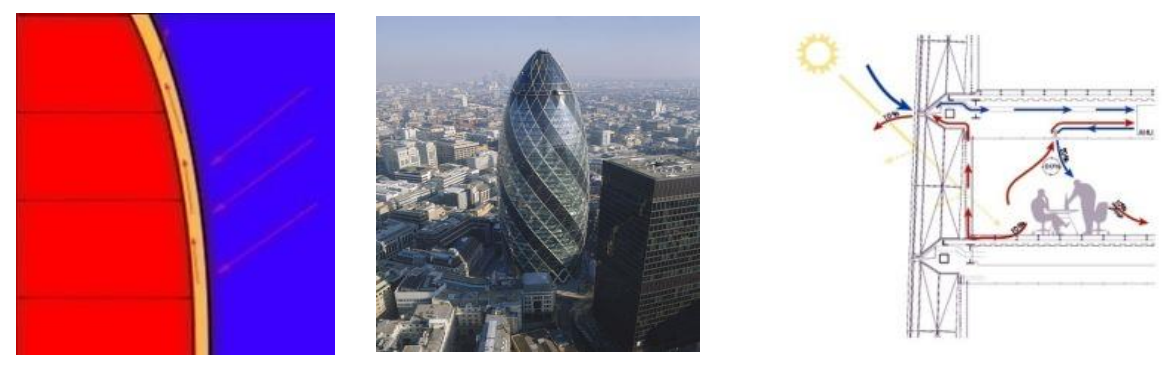

Figure 19: Re-Swiss Tower (mattjohnsonarchitecture.wordpress.com, 2014)

\subsubsection{American University Campus, Cairo, Egypt, Abdul Halim I. CDC and Sasaki and Associates, 2008}

Description: This campus tackle sustainability from every angle to foster a clean and green campus environment, developing a sustainable trash management system and building the university's $1^{\text {st }}$ extensive green roof (www.aucegypt.edu, 2018). The major outdoor gathering space within the campus core, called the Maidan Palm Court, and a series of smaller, sheltered courtyards based upon Middle Eastern designs, with small pools, fountains, palms, flowering shrubs, and groundcovers to maximize natural ventilation and cooling. The large garden would be heavily planted to form a cool, low reservoir. Summer winds from the north would move through the garden and bring cool, moist air into the buildings. Building facades would be heavily planted with deciduous trees to provide shade during summer, allowing sun to filter in during winter (archello.com, 2019). The fundamental goal of AUC design is to be compatible with site conditions and environmental parameters (i.e. the desert climate) from the general plan to the smallest details, the traditions of the university and its Egyptian character. The layout of buildings with shared open spaces, relied mainly on tradition compact design, and the use of courtyards. The environmental criteria include the adaptation to the project's site and location, the use of natural sources of energy, and improving the overall environmental performance, by designing the buildings to surround internal courtyards and appropriately treating external facades. (Selim, 2018). However, the stone walls were constructed to reduce campus energy use by $50 \%$ than 
traditional methods, and more than $75 \%$ of the Alumni campus surrounding wall was recycled from discarded stone waste (Selim, 2011).

Analysis:(It was declared that this campus is a contemporary sustainable design but with bases and flavor of traditional Egyptian sustainable architecture, applying all levels of achieving sustainability and the integration of all their vocabulary, such as the urban, intellectual, environmental, performance, humanitarian and the participatory aspects, employing different design and constructional elements and materials with their treatments.

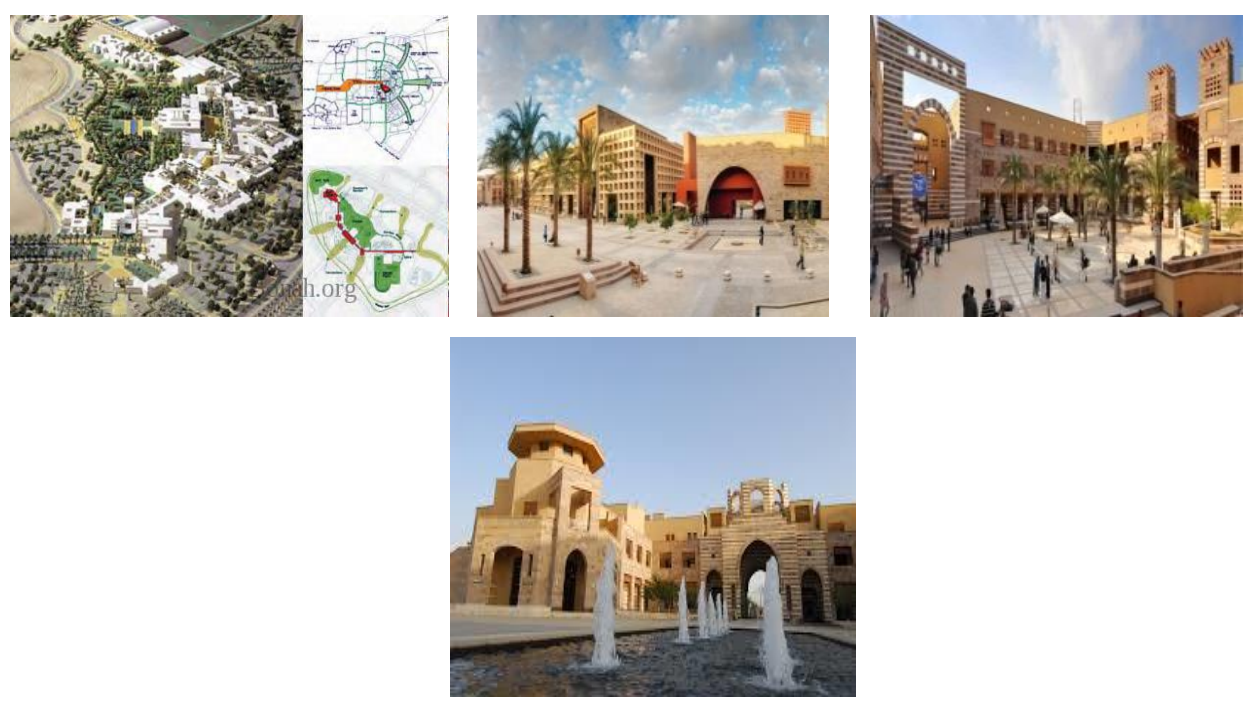

Figure 20: American University Campus, Cairo (archello.com, 2019)

\subsection{Results of the Practical Application}

Results showed that all projects of the applied sample have employed most of the levels of sustainable designs achievement, reached in the theoretical framework paragraph, with focusing on most of the vocabularies, especially, the intellectual and design trends: (the original design trends, the environmental design trends and the sustainable design trends), also the vocabulary of: the architectural and constructional elements, with hybrid combination between the traditional elements and the contemporary ones, as well as the vocabulary of offering different kinds of treatments. All projects concentrate on the performance level concerning issues as:(energy efficiency by (energy reduction and management, self- generating energy and providing the excess energy to neighbors), dynamic concept depending on time dimension in design process ( rotation of parts of the building or stories or the whole building itself), industrialization and smart technologies), also involving the humanitarian level: (with attention to the preventive issues, whereas the participatory issues were less employed in all the projects), and finally some attention was for the level of urban fabric. Results also declared in most of the analyzed examples that there is an extension and preservation of certain sustainable thoughts and technologies related to traditional architecture and identity of place but applied with more creative methods, smart high- tech systems and by using high performing envelope. Finally, most examples clarified the best link between traditional and contemporary sustainable design 
by the employment of different procedures and clear elements as the compact urban fabric, courtyards and passive energy atriums, adaptive reused spaces, vegetation and water.

\section{Conclusions}

1. The conclusions identified clear knowledge of the levels of achieving sustainability in architectural design in both traditional and contemporary architecture with the emphasis on the formation of those levels in the traditional architecture of a strong basis for sustainable architecture known today.

2. As the conclusions declared, the extent of integration and responsiveness between design principles and planning capacities of the traditional architecture, with the local environment and the exploitation of the resources available in the surrounding environment, and social order to establish architecture imply the identity of the place, giving examples of the simplicity of the principles based on,

3. conclusions presented the clear continuity of adopting traditional intellectual concepts of sustainable designs in contemporary architecture by mixing these principles with modern smart technologies to create a renewed hybrid style of architecture emerging from traditions but with modified innovative concepts,

4. Findings also indicated, the many challenges faced by the contemporary architecture in light of the rapid technology developments, reflecting the identity of the age, to prove its ability to accommodate the requirements of sustainable design and the preservation of the environment.

5. Conclusions confirmed the clear role of employing advanced technologies in contemporary architecture in the third millennium and the integration of the environmental, technical and performance aspects, with the design and formation concepts, which carries up architecture to the new stage of performance related to both energy production and dynamic movement of the building within a unit of time, adding a fourth dimension "time" to the design process, transferring the building from static condition to dynamic

6. Findings has explored the clear importance of energy efficiency in contemporary sustainable designs, (such as energy reduction, energy production or excess energy provision to neighbors), in cost reduction and with the emergence of the problems of environmental pollution.

7. It was clear the importance of the principles of: rehabilitation, reuse and preservation) rather than complete elimination to avoid the events of the great change in existing environments.

8. Emerged the clear role of the integration of the Elements of creativity, innovation, concepts of smart architecture, with the principles and techniques of sustainable design.

9. Explored less awareness in applying some levels of sustainability such as the humanitarian aspects of both preventive and participatory aspects in contemporary sustainable designs.

10. Conclusions concentrated the employment of sustainable traditional elements in contemporary architecture, as they are or in a renewed style, after treatment and transformation of their aspects (like size, scale, proportion, function, location, openness---) to be compatible with the techniques of the times. These elements are courtyard, building envelope, openings for natural light and ventilation, ornaments and gathering areas.

11. Also declared the activation of natural resources such as solar energy, wind and certain design methods and materials as they were employed in the traditional buildings instead of using air conditioning and heating systems. 


\section{Recommendations}

1. From the professional view point, the adoption of academic institutions such as universities: (architectural and engineering departments) and governmental institutions to achieve sustainability concepts and design with the dissemination of a culture of environment-friendly buildings, as well as friends of the environment, which may lead to the promotion of the concepts of conservation of natural resources and optimal use and management.

2. Adopt legislation and standards of sustainability concepts compatible with the local environment.

3. The employment of the idea of integrated design work through the participation of all parties in the production of architectural work from the preparation of special studies to planning, design and construction.

4. Activating the role of sustainability learning for students in all stages, at the level of the theoretical approaches and practical projects, and to adopt such themes in the researches of postgraduate studies students.

\section{References}

Al- Khouly, M. (1975). The environmental effects and Arabic architecture. Dar Almaaref, Egypt.

Alter, L. (2010). Green building in Louisville really is green. Retrieved from https://www.thegreenbuilding.net/articles/archives55.htm/

Al-Zubaidy, M. (2001). The use of self-energies in the new cities and their impact on preserving the environment. Planning Standards Conference for Arab Cities, Arab Architects Authority, Libya.

Baiz, H. W., \& Fathulla, J. (2016). Urban courtyard housing form as a response to human need, -Baghdad as a case study. Int. Journal of Engineering Research and Application, 6(9).

Buchanan, P. (2005). Ten shades of green: Architecture and the international world. New York, NY: Architectural League, of New York.

Edward, B., \& Torrent, D. (2000). Sustainable housing: Principles \& practice. E. \& F. N. Spon, UK, London.

Gissen, D. (2003). Big \& Green :Toward sustainable architecture in the 21st century. Princeton Architectural, New York, USA.

Goldhagen, S. W. (2014). Santiago Calatrava's overrated architecture. The New Republic.

Haraty, H. (2015). Typology of Iraqi traditional courtyards houses as Islamic functional spaces in low rise residential units. University of Purta, Malysia.

Haraty, H., Raschid, M., \& Yonus, M. (2018). Exploring architecture patterns of Iraqi traditional courtyard houses. https://www.researchgate.net .

Jameel, K. (2018). In the city of Shanasheel, Iraqi heritage crumbles from budgetary neglect. https://www.rudaw.net,

Mohammad, M., S. (2015). Characteristics and Features of the Dynamic Architecture, The Fourth Dimension in the Architecture-Time. JES, Assiut University, 43(5), 783-806.

Oliver, P. (1997). Encyclopedia of vernacular architecture .Phdaion Press Ltd, London, UK.

Ragette, F. (2003). Traditional Islamic domestic architecture of the Arab region. Axel M. ,Stuttgart.

Raktim, D. (2019). Dynamic architecture / Dynamic tower or Da Vinci Tower, Dubai, (https://www.slideshare.net ).

Randl, C. (2008). Revolving architecture. A history of buildings that rotate, Swivel, and Pivot. New York: Princeton Architectural Press.

Rocca, F. (2009). Believe Him or Not, He Puts a Fresh Spin on Architecture. WSJ.com.

Schoenauer, N. (2000). 6ooo years of housing. W.W. Norton, New York, USA.

Selim, S. (2011). Globalization architecture in Egypt and the absence of sustainability 
concepts in design / case study of administrative buildings in contemporary Cairo.

Engineering Journal/ College of Engineering.

Selim S. H. (2018). Reactions to architectural globalization in the context of Cairo. IJAR, 12(1), 307325.

Shaheen, B., \& Al-Zubaidy, M. (2008). Sustainability principles according to the

Islamic perspective. Iraqi Journal for Architectural Engineering, 4, 12-13.

Swapnika, R. (2019). Dynamic/ DA VINCI/ Rotating Tower, Dubai"-(https://www.slideshare.net/).

Tanta University (2011). Sustainable design and green architecture. College of Architectural Engineering. sustainability@uobabylon.eduiq

Thwainy, A. (2008). Environmental Aptitude in Islamic Architecture. Iraq. Retrieved from www.alnoor.se/article.asp?id=25829

Warren, J. (1982). Traditional houses in Baghdad. Horsham, The Coach Publishing Ltd.

Wall Street Journal, 2008, "Dubai Puts a New Spin on Skyscrapers ", PDF, 2007-04-11.

https://www.archdaily.com/204701/flashback-hearst-tower-foster-and-partners /February 2012.

https://abbis , 2008, "Traditional Courtyard Houses Architecture, Syria.

https://alfozanaward.org, 2011 /Umbrellas in the Mosque of the Prophet's courtyard and surrounding open spaces, Medina, Saudi Arabia/ SL Rasch

http://www.arab-eng.org /2008.

https://archello.com/2019, American University in Cairo Master Plan /IBI Group-Gruzen Samton. https://wwwaucegypt.edu / 2018, Sustainable AUC, The American University in Cairo.

http://www.busyboo.com "12-2007, Architecture, Dynamic Architecture- Modern Architecture". https://www.designbuild-network.com, 2019, "The Rotating Tower Development in Dubai, United Arab Emirates"-Verdict Design build.

https://www.designbuild-network.com/projects/hearst/ 2019, The Hearst Tower/Verdict Media Limite.

https://designlike.com, 2013 /High tech Giant Umbrellas Improve Al Masjid Al Nabawi MosquesNatural Micro Climate/

https:// Emporis.com , Retrieved 01- 04-2008 "Dynamic Architecture Building".

https://en.m.wikipedia.org/2019.

https://en.m.wikipedia.org, 2019, 4 Times Square- Wikipedia .

https://en.wikipedia.org/wiki/2019,Hearst_Tower_(Manhattan)/.

https://en.m.wikipedia.org/ 2019, dynamic tower.

https://imgur.com/gallery/8pbxi , May/2012, Mind Blowing Building Facades.

https://mattjohnsonarchitecture.wordpress.com, Sep. 25, 2014, "Passive and Active Design in the Swiss Re Tower - Systems, Sites, and Buildings.

https://www.podand.com /2010, The Green Building Mixed-Use.

https://www.slideshare.net/ Reddy.

http://wirednewyork.com/skyscrapers/4-times-square/ 2013, The Conde Nast Building, Wired New York. 